SCIENTIFIC COMMUNICATION

\title{
The correct use of the vernacular names for South American dolphins genus Sotalia Gray (Mammalia, Cetacea, Delphinidae)
}

\section{Lena Geise}

Laboratório de Mastozoologia, Departamento de Zoologia, Instituto de Biologia, Universidade do Estado do Rio de Janeiro. Rua São Francisco Xavier 524, PHLC, Sala 513 A, Maracanã, 20550-013 Rio de Janeiro, Rio de Janeiro, Brasil.

E-mail: geise@uerj.br

\begin{abstract}
The usage of the vernacular names for South American dolphins genus Sotalia Gray, 1866 is discussed in accordance to geographic characteristics of local people identification.

KEY WORDS. Gray dolphin; taxonomic status, Tucuxi.
\end{abstract}

RESUMO. O uso correto de nomes vernaculares dos botos sul-americanos do gênero Sotalia Gray (Mammalia, Cetacea, Delphinidae). O uso de nomes vernaculares para os botos sul-americanos do gênero Sotalia Gray, 1866 são discutidos de acordo com as características geográficas das identificações feitas pelas populações litorâneas. PALAVRAS-CHAVE. Boto-cinza; status taxonômico; Tucuxi.

Coastal dolphins in South America of the genus Sotalia (Cetacea, Delphinidae) were described by GraY (1866) based on a single specimen's skull from French Guyana. The mane S. guianensis was erected by VAN BÉNÉDEN (1864), S. fluviatilis by Gervais \& Deville (1853) for specimens of the Amazon basin and S. brasiliensis by VAN BÉNÉDEN (1875) for specimens exclusively from the Guanabara Bay, in Rio de Janeiro. Studies showed that the genus occurs from Florianópolis region, in Santa Catarina (SIM ÕEs-LOPES 1988) up to Honduras (SILVA \& BEST 1996), being also observed in some coastal habitats as estuaries (GEISE et al. 1999), bays and rivers (SILVA \& BEST 1994, 1996). An unpublished study (cited in MonteIRo-FILHo et al. 2002) pointed out some cranial differentiation among $\mathrm{S}$. guianensis and $\mathrm{S}$. fluviatilis samples but proposed the genus as being monotypic. This approach, even in disagreement to the taxonomic rules was accepted by most researchers (e.g. RICE 1998, SILVA \& BEST 1996, WiLson \& REEDER 2005), who also recognizes a single species - S. fluviatilis - with two ecotypes, one marine and one of freshwater.

Recently, CunHa et al. (2005) showed, based on molecular evidence, that the two ecotypes actually correspond to welldefined taxonomic units, thus deserving to be granted specific level. Sotalia guianensis, the marine species, and S. fluviatilis that inhabit the Amazon basin were already separated by Monteiro-FilHo et al. (2002) on morphometric grounds. These authors showed that they are different in cranial shape. Consequently, the synonymy proposed in the 1980s (SILVA \& BEST 1994, 1996) must now be considered invalid.
Ecological and biogeographic approaches also corroborate such taxonomic status, as the marine Sotalia occurs in almost all South and Central America coastal areas (SILVA \& BEST 1994, 1996, MonTEIRO-FILHo et al. 2002), and the freshwater species is probably restricted to the Amazon basin. Further investigations concerning the entrance of marine specimens in the riverine area of the Amazon river, and its extent, and the usage of coastal area by freshwater specimens may provide more detailed information about simpatry or even inbreeding and genetic flow.

Together with the synonimization adopted by all aquatic mammals researchers, the usage of the Amazonian popular name for Sotalia, which is commonly known there as 'Tucuxi' was improperly adopted for the former marine ecotype of $\mathrm{S}$. fluviatilis (WILSON \& REEDER 2005). As such popular name is completely unknown by fishermen and other local people in the whole Brazilian coastal area, such denomination is not in agreement with the so-called usage of vernacular names. Thus, in order to follow the correct taxonomic status of these two species, I suggest the adoption of 'Tucuxi' (derived from the Tupi language), only for S. fluviatilis. Other common names will also be better used for marine Sotalia from French Guiana up to Honduras, in Central America, according to local tradition, as Guiana white dolphin, guiana river dolphin (Husson 1978) or Guiane Dolphin (Rıce 1998). In the Brazilian coastal area S. guianensis is usually called by fishermen and expertise as 'boto' or 'boto-cinza' (gray dolphin) (e.g. MontelRo-Filho et al. 2002, DAURA-Jorge et al. 2004) or estuarine dolphin (e.g. WATSON 1988, 
DAURA-JORGE et al. 2005). The vernacular name gray dolphin is also used for Grampus griseus (Rice, 1998). Such duplication of vernacular names by local population is common and different according to the region where each of those species are more commonly seen by fishermen, making a correct identification trough such denomination only acceptable after a careful certification.

\section{ACKNOWLEDGMENTS}

The manuscript was improved by comments from D.A. de Moraes, V. Gallo, and E. Faerstein. This work is supported by CNPq (fellowship) and UERJ/Prociência.

\section{REFERENCES}

Cunha, H.A., V.M.F. da Silva; J. Lailson-Brito JR; M.C.O Santos; P.A.C. Flores; A.R. Martin; A.M. Azevedo; A.B.L Fragoso; R.C. Zanelatto \& A.M. Solé-Cava. 2005. Riverine and marine ecotypes of Sotalia dolphins are different species. Marine Biology, Berlin, 148: 449-457.

Daura-Jorge, F.G.; L.L. Wedekin \& P.C. Simões-Lopes. 2004. Variação sazonal na intensidade dos deslocamentos do boto-cinza, Sotalia guianensis (Cetacea: Delphinidae), na Baía Norte da Ilha de Santa Catarina. Biotemas, Florianópolis, 17 (1): 203-216.

Daura-Jorge, F.G.; L.L. Wedekin; V. de Q. Piacentini \& P.C. SimõesLOPES. 2005. Seasonal and daily patterns of group size, cohesion and activity of the estuarine dolphin, Sotalia guianensis (P.J. van Bénéden), in southern Brazil. Revista Brasileira de Zoologia, Curitiba, 22 (4): 1014-1021.

Geise, L.; N. Gomes \& R. Cerqueira. 1999. Behaviour, habitat use and population size of Sotalia fluviatilis (Gervais, 1853) (Cetacea, Delphinidae) in the Cananéia estuary region, São Paulo, Brazil. Revista Brasileira de Biologia, Curitiba, 59 (2): 183-194.

Gervais, F.L.P. [\& DevilLe]. 1853. Sur les mammiféres marins qui fréquentent les côtes de la France et plus particulìerement sur une nov elle espéce de dauphins proprea la Méditerranés.
Bulletin Sociéte Centrale d'Agriculture et des Comices Agricoles du Département de l'Herault, 40me année, Montpellier: 140-155.

Gray, J.E. 1866. Catalogue of Seals and Whales in the British Museum. London, British Museum (Natural History) Department of Zoology, $2^{\text {nd }}$ ed., 402p.

Husson, A.M. 1978. The mammals of Suriname. Zoölogische Monographeieen van het Rijksmuseum van Natuurlijke Historie, Leiden, 2: 1-569.

Monteiro-Filho E.L.A.; L.R. Monteiro \& S.F. Reis. 2002. Skull shape and size divergence in dolphins of the genus Sotalia: A tridimensional morphometric analysis. Journal of Mammalogy, Lawrence, 83: 125-134.

RICE D.W. 1998. Marine mammals of the world: Systematics and distribution. Lawrence, The Society for Marine Mammalogy, Special Publication, 230p.

SIMÕES-LOPES, P.C. 1988. Ocorrência de uma população de Sotalia fluviatilis Gervais, 1853 (Cetacea, Del phinidae) no limite sul de sua distribuição, Santa Catarina, Brasil. Biotemas, Santa Catarina, 1 (1): 57-62.

SiLva, V.M.F. \& R.C. BEST. 1994. Tucuxi, Sotalia fluviatilis (Gervais, 1853), p. 43-69. In: S.H. RIDGWAY \& R. HARRISON (Eds). Handbook of Marine Mammals. London, Academic Press, 416p.

SILVA, V.M.F. \& R.C. BEST. 1996. Sotalia fluviatilis. Mammalian Species, Northampton 527: 1-7.

VAN BÉnÉDEN, E. 1875. Mémoire sur un Dauphin nouveau de la Baie de Rio de Janeiro, désigné sous le nom de Somalia brasiliensis. Mémoires de l'Académie Royale de Sciences Belgique, Bruxelles, 41 (1): 1-44.

VAN BÉnÉDEN, P. 1864. Sur un Dauphin nouveau (Delphinus guianensis) et um Ziphioiderare. Memmoires del'Academie Royale de Sciences Belgique, Bruxelles, 16: 1-21.

WATSON, L. 1988. Whales of the World. A complete guide to the world's living whales, dolphins and porpoises. London, Hutchinson, 302p.

WILSON D.E. \& D.M. ReEDER. 2005. Mammal Species of the World. A Taxonomic and Geographic Reference. $3^{\text {nd }}$ edition. Johns Hopkins University Press, Baltimore, XXXV+2142p.

Received in 15.IX.2005; accepted in 21.IX.2006. 